\title{
Lifestyle and wellbeing: Exploring behavioral and demographic covariates in a large US sample
}

\author{
Johannes C. Eichstaedt · David B. Yaden · Fernando Ribeiro \\ Alejandro Adler · Margaret L. Kern
}

\begin{abstract}
Using data from a nationally representative sample of 46,179 US adults from the Gallup-Healthways Wellbeing Index, we investigate covariates of four subjective mental wellbeing dimensions spanning evaluative (life satisfaction), positive affective (happiness), negative affective (worry), and eudaimonic wellbeing. Negative covariates were generally more strongly correlated with the four dimensions than positive covariates, with depression, poor health, and loneliness being the greatest negative correlates and excellent health and older age being the greatest positive correlates. We reproduce previous evidence for a "midlife crisis" around age 50 across the four wellbeing dimensions. Notably, although salutogenic behaviors (diet, exercise, socializing) correlated with greater wellbeing, there were diminishing benefits beyond thresholds of about four hours a day spent socializing, four days per week of consuming fruits and vegetables, and four days per week of exercising. Findings suggest that wellbeing is easier lost than gained, underscore the influence that relatively malleable lifestyle factors have on wellbeing, and stress the importance of multidimensional measurement for public policy.
\end{abstract}

Keywords: subjective wellbeing, mental health, income, health, public policy, health behaviors

\section{Introduction}

Recent decades have brought a growing focus on wellbeing, with all 193 United Nations (UN) member countries officially adopting the promotion of wellbeing for all people as a national policy goal, as reflected in the 2030 UN Sustainable Development Goals (SDGs; Costanza et al. 2016; Izutsu et al., 2015). Specifically, SDG 3.4 calls for all countries to make "mental health and well-being" a priority in the measurement, design, implementation, and evaluation of their policies and their national agendas (UN, 2015). Decisions that substantially influence the wellbeing of large numbers of people ought to be supported by data (Davies, 2002). Data provide the possibility to monitor the effectiveness of policy initiatives, returns on investments, and the value derived from a management or policy decision. Over time, data offer opportunities to define strategies, policies, and implementation plans, as well as to set standards that allow comparisons among individuals, organizations, communities, and nations to be made (Chattopadhyay, 2016). However, as collecting appropriate data is time and resource-intensive, useful indicators need to be carefully selected.

Wellbeing has historically been measured objectively through proxies such as income, life expectancy, educational attainment, unemployment, and crime. However, wellbeing science has increasingly emphasized the utility of subjective indicators (Helliwell \& Aknin, 2018). Happiness, self-actualization, and subjective wellbeing have long been considered valuable and 
desirable parts of life (Csikszentmihalyi, 1999; Diener, 2000; Diener, Lucas, \& Oishi, 2009; Maslow, 1943; Melchert, 2002), but through much of the $20^{\text {th }}$ century, they remained primarily niche areas of theory, research, and practice (Seligman, 2011; Sheldon \& Kind, 2001). The 21 ${ }^{\text {st }}$ century has brought subjective perspectives into the forefront of scientific research and policy consideration, driven in part by a growing ability to validly and reliably measure subjective wellbeing at individual and national levels (cf. Diener, Lucas, \& Oishi, 2002).

At the societal level, considerations of subjective wellbeing data have primarily focused on evaluative measures, which ask respondents the extent to which they are satisfied with their life as a whole (e.g., Diener, Inglehart, \& Tay, 2012; Helliwell, Huang, \& Wang, 2017). A growing number of affective (e.g., positive and negative emotions) and eudaimonic (e.g., the sense of life being meaningful and engaging) measures have also been developed and trialed globally (see Durand, 2018; Durand \& Exton, 2019; OECD, 2020). Other measures include physical, social, spiritual, and functional dimensions.

While several recent analyses suggested that multiple wellbeing dimensions are indistinguishable (Disabato et al., 2016; Goodman et al., 2018), other wellbeing researchers argue for the practical benefits of incorporating multiple dimensions (e.g., Adler \& Seligman, 2016; Forgeard et al., 2011; Kern, Waters, Adler, \& White, 2015; McQuaid \& Kern, 2017; Seligman, 2018). Using a large, nationally representative sample and well-controlled analyses, here we examine four dimensions of subjective wellbeing: evaluative, positive affective, negative affective, and eudaimonic. We consider how each dimension relates to a variety of demographic, economic, health, and behavioral correlates, with an emphasis on those factors and conditions that may be amenable to alteration through public policy initiatives.

\subsection{The Value of subjective wellbeing measures}

Researchers have long argued about the constituents and key determinants of wellbeing (Easterlin, 2003; Lyubomirsky, Sheldon, \& Schkade, 2005; Perovic \& Golem, 2010). One major debate in this area consists of whether one should use subjective or objective measures of wellbeing (Helliwell \& Barrington-Leigh, 2010; Kahneman, 1999; Ryff, 1989). Subjective reports are impacted by self-perception and self-presentation biases (Schwarz \& Strack, 2016), and when comparing across cultures, variations that occur in terms of reference groups, response styles, and desired outcomes can impact the extent to which responses are comparable (Baumgartner \& Steenkamp 2001; Heine et al., 2002; Hornsey et al., 2018; Kern, Zeng, Hao, \& Peng, 2018). More recent areas of work involve exploring possibilities for complementing self-report measures with a variety of unobtrusive methods, such as computational linguistic analyses of social media data (e.g., Eichstaedt et al., 2015; Guntuku, Yaden, Kern, Ungar, \& Eichstaedt, 2017; Schwartz et al., 2013; Jaidka et al., 2020). At present, however, economists and policymakers have primarily focused on objective indicators, such as wealth and gross domestic product (GDP).

Yet objective measures fail to capture what actually matters to people's lived experience (Kennedy, 1968). While theoretical discussions regarding the construction, validity, reliability, and implications of wellbeing measurements are on-going, a growing consensus has emerged around the importance of directly measuring subjective wellbeing and using that data to inform economic discussions (Layard, 2010). Measurements of subjective wellbeing can provide nuances and checks on what economic indicators capture (Bergheim, 2006; Diener \& Seligman, 2004; Diener, Oishi, \& Lucas, 2015; Kahneman, Krueger, Schkade, Schwarz, \& Stone, 2006). For example, psychologists and economists have demonstrated that income levels and various kinds of expenditures differentially impact reports of wellbeing (Easterlin, McVey, Switek, Sawangfa, \& Zweig, 2010; Reyes-Garcia et al., 2016), finding that beyond a threshold, higher national 
incomes do not bring commensurate increases in wellbeing (e.g., Diener \& Seligman, 2004; Kahneman \& Deaton, 2010). Measurements of subjective wellbeing may also provide valuable information that policy makers, healthcare decision makers, and organizational professionals may use to guide their decision-making processes, such as how subjective wellbeing interacts with the quality of public services and views of progressive taxation (Diener et al., 2017; Oishi, Schimmack, \& Diener, 2012).

Within the subjective wellbeing literature, various measures have been developed, aligned with specific theoretical conceptualizations of wellbeing. Measures such as the 36-item Short Form Survey (SF-36) include physical (vitality, physical functioning, bodily pain, general health perceptions, and physical role functioning), mental (emotional role functioning and mental health) and social (social role functioning) dimensions (Ware, 2000). The mental health dimension can further be broken into evaluative, affective, and eudaimonic dimensions, encapsulating a number of domains (Chia, Kern, \& Neville, 2020; Diener, 2006; Dolan, Layard, \& Metcalfe, 2011; Dolan \& Metcalfe, 2012). For instance, Ryff's (1995) psychological wellbeing model includes six domains: self-acceptance, positive relationships with others, autonomy, environmental mastery, purpose in life, and personal growth. Seligman's (2011) Wellbeing Theory delineates five domains of life that people pursue for their own sake: positive emotion, engagement or flow, positive relationships, meaning or purpose, and achievement.

Subjective wellbeing data has increasingly become assessed and monitored globally. In the 1970s, the king of Bhutan, Jigme Singye Wangchuck, provocatively declared that "[g]ross national happiness is more important than gross domestic product" (OPHI, n.d., para 1). In 2001, Australia established a framework to monitor national wellbeing (Webste, Bode, \& Posselt, 2008). Following the Stiglitz-Sen-Fitoussi (2009) report to the French government on the importance of including various social, economic, and environmental indicators of national progress that go beyond GDP, subjective perspectives of wellbeing gained traction. Multilateral organizations have furthered their interest in developing beyond-GDP measures of national progress, including work to advance the measurement of subjective wellbeing (Fox, 2012; OECD, 2013; 2020). Further, many countries have adopted wellbeing as an explicit government goal. For instance, since 2009, Bhutan has used "Gross National Happiness" to drive government policy design, implementation, and evaluation (Adler, 2009; Anderson \& Mossialos, 2019; ONS, 2011; 2015; Waldron, 2010), and in 2019, New Zealand established an official "wellbeing budget" for allocating public financing.

\subsection{Capturing subjective wellbeing data}

While these initiatives have established the value of subjective wellbeing data, the question becomes which measures should a nation deploy? Different measurement approaches may lead to discrepant inferences from the data (Dolan \& Metcalfe, 2012). Here we specifically focus on subjective measures that focus on the mental dimension. Within this dimension, although the debate about what exact data to collect is bound to continue, researchers have converged around three primary types due to their theoretical rigor, relevance in policy decisions, and empirical robustness, which can be characterized as: evaluative, affective, and eudaimonic (Diener, 2006; Dolan, Layard, \& Metcalfe, 2011; Dolan \& Metcalfe, 2012).

Evaluative wellbeing measures describe a global assessment of an individual's appraisal of their overall wellbeing. Examples of common evaluative wellbeing measures include the Satisfaction with Life Scale (SWLS, Diener, Emmons, Larsen, \& Griffin, 1985), the Life Satisfaction Index (LSI, Wallace \& Wheeler, 2002), and the Quality of Life Inventory (QoLI, Frisch, Cornell, Villanueva, \& Retzlaff, 1992). In national surveys, evaluative wellbeing is most typically assessed 
with a single question, such as "how satisfied are you with your life overall" (Dolan et al., 2011; Kapteyn et al., 2015) or indicating on a ladder (ranging from the worst possible life to the best possible life one can imagine) how the person is feeling (Cantril, 1965; Gallup, 2016).

Affective wellbeing measures capture how respondents feel at a certain point in time (Dolan et al., 2011; Kapteyn, 2015). Affective measures can be further broken down into positive affect (e.g., happiness, contentment) and negative affect (e.g., sadness, anger). Although positive and negative affect are generally inversely correlated, they are also independent factors (Keyes, 2002; Watson, Clark, \& Tellegen, 1988). Common affective wellbeing measures include the Affect Balance Scale (ABS, Bradburn, 1969) and the Positive and Negative Affect Scale (PANAS, Watson, Clark, \& Tellegen, 1988). Single item measures of affective wellbeing include "Overall, how worried did you feel yesterday?" (OECD, 2013).

Eudaimonic wellbeing measures emphasize the pursuit and experience of the good life (Maddux, 2012; Maslow, 1943; Ryan \& Deci, 2001; Ryff, 1989). Measures include constructs such as autonomy, competence, personal growth, and a sense of meaning and purpose in life. Examples of eudaimonic wellbeing measures include the Purpose in Life Scale (PIL, Marsh, Smith, Piek, \& Saunders, 2003), the Life Engagement Test (LET, Scheier et al., 2006), and the Questionnaire for Eudaimonic Wellbeing (QWEB, Waterman et al., 2010). Single item measures of eudaimonic wellbeing include "Most days I get a sense of accomplishment from what I do" and "I am free to decide for myself how to live my life" (OECD, 2013).

Although some recent work casts doubt on whether hedonic and eudaimonic forms of wellbeing are separable (Goodman, Disabato, Kashdan, \& Kaufman, 2018), other factor analytic studies support the primacy and distinctiveness of these four dimensions of wellbeing (Diener et al., 2017). For instance, Kapteyn and colleagues (2015) demonstrated that evaluative (life satisfaction) and positive/negative affective wellbeing constitute distinct factors. White and Dolan (2009) distinguished perceptions of how rewarding an activity was from the positive affect that a given activity elicits. Multidimensional scaling demonstrates that eudaimonic and affective dimensions of wellbeing are qualitatively different (Joshanloo \& Weijers, 2019), and exploratory structural equation modeling demonstrates that eudaimonic and affective dimensions are quantitatively different (Joshanloo, 2019). In a series of randomized controlled studies, eudaimonic domains enhanced adolescent learning outcomes in adolescents, whereas affective domains did not (Seligman \& Adler, 2018; 2019). Other studies have further support distinctions between the eudaimonic and affective dimensions, with the former correlated with personal growth through struggle and the latter correlated with the pleasant and easy parts of life (e.g., Baumeister, Vohs, Aaker, \& Garbinsky, 2013; Vittersø, Søholt, Hetland, Thoresen, \& Røysamb, 2009; Waterman, 1993).

From a public policy perspective, multiple dimensions are useful to the extent that they have different correlates. Evaluative measures-especially life satisfaction-are the most commonly used subjective wellbeing measures, and thus provide the widest ground for international comparisons of wellbeing. But the evaluative dimension alone paints an incomplete picture, as affective and eudaimonic dimensions influence life evaluations (Helliwell et al., 2017). Studies are thus needed on the distinctive correlates of multiple wellbeing dimensions to best inform policies that effectively promote flourishing (Adler \& Seligman, 2016).

\subsection{Applying wellbeing measurement within national surveys}

Beginning in 2011, the Office for National Statistics (ONS) of the United Kingdom added four questions to its Annual Population Survey (Steel, 2016a, 2016b), which map roughly onto the four dimensions described above: “how satisfied are you with your life nowadays?" (evaluative), 
"how happy did you feel yesterday?" (positive affect), "how anxious did you feel yesterday?" (negative affect), and "to what extent do you feel the things you do in your life are worthwhile?" (eudaimonic). These questions have become known as the "ONS4." The ONS has since produced numerous publications exploring the use and correlates of these items (see https://www.ons.gov.uk/peoplepopulationandcommunity/wellbeing).

Since the creation of the ONS4 and the Gallup-Healthways Wellbeing Index (GHWI, described below), studies have leveraged these and other wellbeing datasets to try to determine their influencing factors, correlates, and predictors. For example, Lawless and Lucas (2011) used data from the Centers for Disease Control and Prevention (CDC) to examine the correlates of life satisfaction at a US county level, confirming regional variance in wellbeing, with life satisfaction consistently correlating positively with income, population density, health, and education. Chanfreau and colleagues (2013) found that wellbeing was lower among the oldest, in midlife, and in mid adolescence compared to other age groups, and found that social relationships were protective across age groups and genders. Chandler (2016) compared employees' health and wellbeing in the Manchester region to the UK global survey, finding that employees who felt more control over their work and who felt supported at work, had higher levels of health and wellbeing. Collins (2016) considered the social return on investment of measuring wellbeing in the Wirral population in North West England, outlining the significant economic costs of changes in short term wellbeing and illbeing.

\subsection{The current study}

The GHWI collected data from 2008 to 2018, and more than two million people have responded to the survey questions. The survey includes wellbeing questions that generally align with the ONS4, allowing investigation of the behavioral and demographic covariates of wellbeing that might be impacted by policy. We explore the correlational profile of the four subjective mental wellbeing dimensions in a large US sample $(\mathrm{N}=46,179)$ with a series of economic, demographic, health, and behavioral variables, with specific focus on lifestyle indicators.

\section{Method}

\subsection{Participants}

The current study uses a subset of data from the Gallup-Healthways Wellbeing Index (Gallup, 2018). From 2008 to 2018, 500 to 1,000 individuals were interviewed each day throughout the year. Gallup uses different methods to assure sample randomization including dual-framing sampling and telephone random digit dial (RDD). Interviews were conducted in English or Spanish. Gallup's sample is thus representative of $95 \%$ of the American adult population (Gallup, 2016).

We include 46,179 US respondents who were interviewed between January 2013 and December 2016. Respondents were excluded if their interview was incomplete or they were missing values across the target variables. Demographic information (gender, race, education, income, age group) are summarized in Table 1 (below). Nearly half of the sample was female $(48 \%)$ and the average age of the sample was 52.4 years $(S D=18$, range $=18$ to 99$)$. 
Table 1. Descriptive statistics on the Gallup sample $(N=46,179)$

\begin{tabular}{|c|c|c|c|c|}
\hline & & Frequency & Percent & $\begin{array}{c}\text { Cumulative } \\
\text { Percent }\end{array}$ \\
\hline \multirow{2}{*}{ Gender } & Male & 23,787 & 51.5 & 51.5 \\
\hline & Female & 22,392 & 48.5 & 100.0 \\
\hline \multirow{6}{*}{ Race } & White & 35,815 & 77.6 & 77.6 \\
\hline & Asian & 4,213 & 9.1 & 86.7 \\
\hline & Hispanic & 3,947 & 8.5 & 95.2 \\
\hline & American Indian / Alaska Native & 1,048 & 2.3 & 97.5 \\
\hline & Black & 682 & 1.5 & 99.0 \\
\hline & Not reported & 474 & 1.0 & 100.0 \\
\hline \multirow{4}{*}{ Education } & Up to including High School & 11,863 & 25.7 & 25.7 \\
\hline & Technical / vocational program or some college & 14,303 & 31.0 & 56.7 \\
\hline & College graduate (bachelor or 2-year associate) & 10,859 & 23.5 & 80.2 \\
\hline & Some postgraduate or postgraduate degree & 9,154 & 19.8 & 100.0 \\
\hline \multirow{5}{*}{$\begin{array}{l}\text { Monthly } \\
\text { Income }\end{array}$} & $<\$ 1,000$ & 3,153 & 6.8 & 6.8 \\
\hline & $\$ 2,000-\$ 3,999$ & 16,451 & 35.6 & 42.5 \\
\hline & $\$ 4,000-\$ 7,499$ & 13,817 & 29.9 & 72.4 \\
\hline & $\$ 7,500-\$ 9,999$ & 4,406 & 9.5 & 81.9 \\
\hline & $\$ 10,000$ or above & 8,352 & 18.1 & 100.0 \\
\hline \multirow{5}{*}{ Age } & $18-19$ & 1,556 & 3.4 & 3.4 \\
\hline & $20-39$ & 11,477 & 24.9 & 28.2 \\
\hline & $40-59$ & 16,056 & 34.8 & 63.0 \\
\hline & $60-79$ & 14,818 & 32.1 & 95.1 \\
\hline & $80-99$ & 2,272 & 4.9 & 100.0 \\
\hline
\end{tabular}

\subsection{Measures}

Wellbeing. We identified the Gallup questions that most closely matched the four wellbeing questions asked by the Office for National Statistics in the United Kingdom (ONS4; ONS, 2016) to capture evaluative, positive affective, negative affective, and eudaimonic subjective mental wellbeing. Single questions asked respondents to rate their satisfaction with life (evaluative), and feelings of happiness (positive affective) and worry (negative affective), and two items reflected eudaimonic wellbeing ("I learn or do something interesting every day," "You like what you do every day.") (see Table 2). Unfortunately, the questions had different response options: life satisfaction was on a 0 to 10 scale, positive and negative affect were yes/no questions, and eudaimonic questions were on a 1 to 5 scale. As we aimed to compare the importance of a large list of covariates on the four wellbeing dimensions, we opted to equalize variance by dichotomizing the variables based on median splits for the continuous variables and no alterations for the dichotomous variables. This allowed us to compare the relative impact of covariates across the wellbeing dimensions. The same analytic choice was made by Kahneman and Deaton's (2010) work using the GHWI. As a robustness check, we reproduced the analysis with the continuous variables (see Supplemental Table S1). A similar pattern of results occurred, 
although dichotomizing variables somewhat attenuated the size of the standardized coefficients. ${ }^{1}$ Across the wellbeing variables, higher scores are better (greater life satisfaction, positive affect, and eudaimonic wellbeing; lower negative affect).

Covariates. As summarized in Table 2, we selected variables from the GHWI that capture demographic, economic, health, and behavioral domains. We chose variables following previous similar studies (Kahneman \& Deaton, 2010; Kahneman, Schkade, Fischler, Krueger, \& Krilla, 2010) $)^{2}$ :

1. Socio-economic variables: low/high income, education, and health insurance status

2. Demographic variables: gender, old age (being over 59 years of age), married/divorced

3. Health variables: self-reported health status (poor or excellent), depression, and obesity

4. Behavioral variables: exercise (three or more times a week), smoker, being alone (zero hours of social contact yesterday), and good diet (eating fruits and vegetables more than three times a week)

Following our rationale outlined above, for the main analyses, all covariate variables were dichotomized, maximizing the extent to which their relative importance can be compared.

\section{Table 2. Variable definitions}

\begin{tabular}{|c|c|c|}
\hline \multicolumn{3}{|c|}{ Dependent Variables (DV) } \\
\hline Name & Scale Type & Definition \\
\hline Evaluative & Dichotomous & Any person who reports having a life satisfaction equal to or greater than 7 \\
\hline Positive Affect & Dichotomous & Any person who claims to have experienced happiness the day before \\
\hline Low Negative Affect & Dichotomous & Any person who claims to have experienced low worry the day before \\
\hline Eudaimonic & Dichotomous & $\begin{array}{l}\text { Any person reporting doing what s/he likes every day or learning or doing something interesting } \\
\text { each day (average of both answers above } 4 \text { in a scale from } 1 \text { to } 5 \text { ) }\end{array}$ \\
\hline \multicolumn{3}{|c|}{ Independent Variables (IV) } \\
\hline Name & Scale Type & Definition \\
\hline Female & Dichotomous & Any person whose declared gender is female \\
\hline Old & Dichotomous & Any person older than 59 years of age \\
\hline Married & Dichotomous & Any person who declares to be married \\
\hline Divorced & Dichotomous & Any person who declares to be divorced \\
\hline High Income & Dichotomous & Any person with earnings above $\$ 7,500$ a month \\
\hline Low Income & Dichotomous & Any person with earnings below $\$ 3,000$ a month \\
\hline Insured & Dichotomous & Any person with health insurance \\
\hline Graduate & Dichotomous & Any person who has an undergraduate or higher degree \\
\hline Excellent Health & Dichotomous & Any person who claims her health to be excellent ( 5 in a scale from 1 to 5 ) \\
\hline Poor Health & Dichotomous & Any person who claims her health to be fair or poor ( 1 or 2 in a scale from 1 to 5 ) \\
\hline Obese & Dichotomous & Any person who has a body-mass index (BMI) equal to or greater than 30 \\
\hline Depressed & Dichotomous & Any person that is depressed \\
\hline Exercise & Dichotomous & Any person who exercises for 30 or more minutes more than $2 x$ a week \\
\hline Good Diet & Dichotomous & Any person who has five or more servings of fruits and vegetables more than $3 x$ a week \\
\hline Alone & Dichotomous & Any person who spent no time socially with friends or family the day before (virtual or real time) \\
\hline Smoker & Dichotomous & Any person who smokes (any frequency) \\
\hline Weekend Satisfaction & Dichotomous & Dummy variable to account for weekend effect for evaluative and eudaimonic wellbeing \\
\hline Weekend Happiness & Dichotomous & Dummy variable to account for weekend effect for affect variables \\
\hline
\end{tabular}

\footnotetext{
${ }^{1}$ The greatest difference between the dichotomized and continuous wellbeing variables occurred for poor health, with reductions of the standardized coefficient by 0.06 through dichotomization.

${ }^{2}$ Kahneman and Deaton (2010) also included being a caregiver and having headaches, but these were inconsistently asked within the GHWI, so excluded here.
} 


\subsection{Data analyses}

Main regressions. Analyses were conducted using the $1 \mathrm{~m}$.beta package (Behrendt, 2014) in $\mathrm{R}$ software. We considered the dichotomized wellbeing variables as the dependent variables and the other variables as the independent variables. We first calculated point-biserial correlations amongst the study variables. The independent variables were then included in OLS linear regressions, repeating for each of the four wellbeing variables. All linear models were regressed using the formula: $\mathrm{Y}=\sum_{i=1}^{n} \beta_{n} X_{n}$. The full model (repeated for each wellbeing component) was estimated as:

Wellbeing $=$ Gender + Age + Married + Divorced + High Income + Low Income + Insured + Graduate

+ Excellent Health + Poor Health + Obese + Depressed + Exercise + Veggies + Alone + Smoker + Weekend

We report the resulting standardized coefficients.

Supplemental analyses. The main analyses aimed to maximize comparability, and thus used dichotomized values across variables. As a supplemental analysis, for a subset of the covariate variables that had meaningful continuous response options (hours spent socially, number of days with 30+ minutes of exercise, number of days with five or more servings of fruits and vegetables, and age), we considered how different levels of the covariates predicted the wellbeing dimensions. For the life satisfaction and eudaimonic questions, we also used the continuous variables. The supplemental analyses investigated the presence of satiation points in the behavioral variables and identifying variability across age.

\section{Results}

Table 3 shows the correlations amongst the study variables. Although the four wellbeing dimensions were related, correlations were only small to moderate in size (range $r=.18$ to .26 ). These values are smaller than in other studies. This is at least partly due to the constrained variance due to the dichotomization of the variables, although the intercorrelation between continuous life satisfaction and eudaimonic scores remained modest $(r=.37)$.

Table 3. Wellbeing (dichotomous) variables and its correlations with independent variables

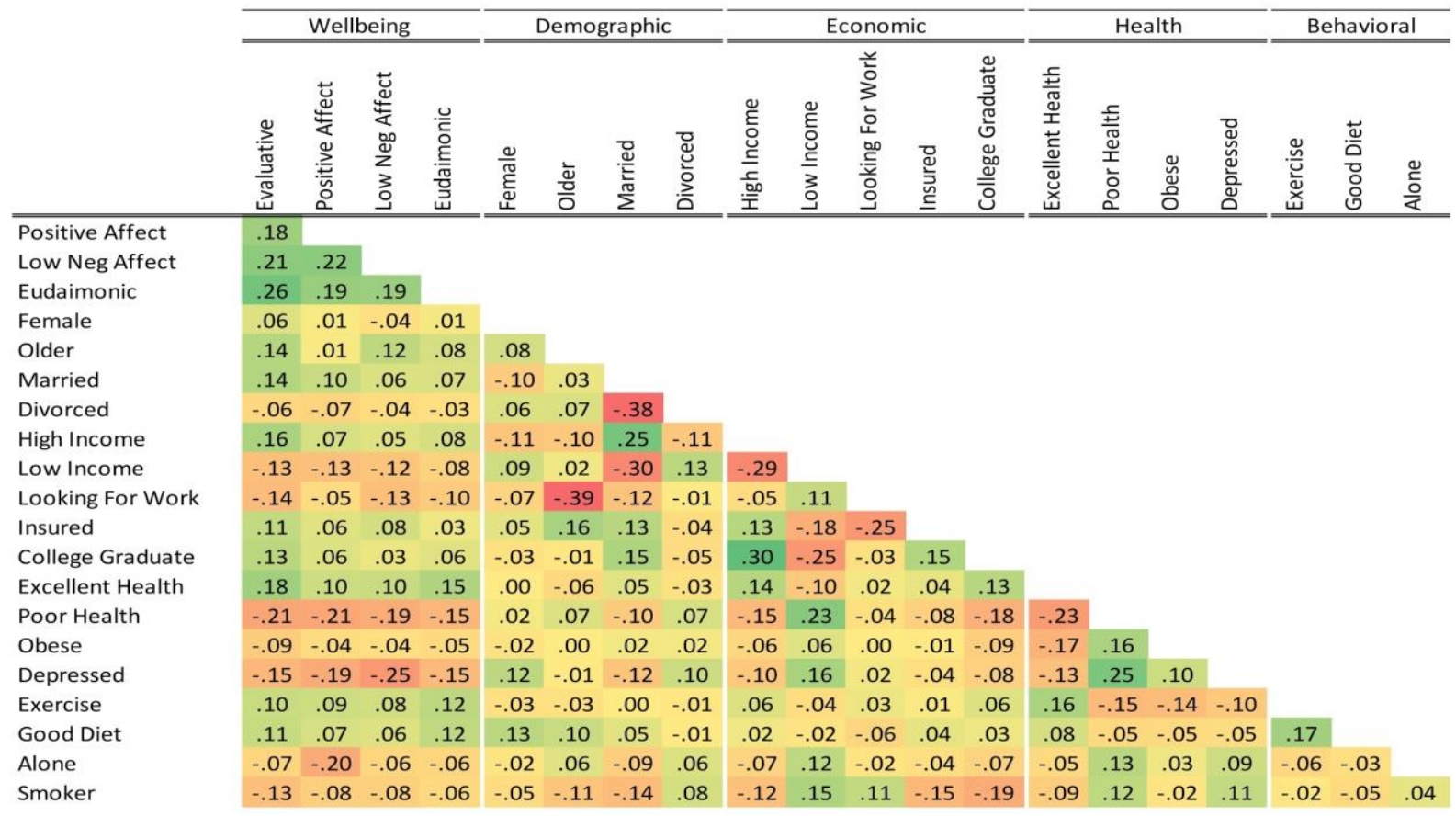


We then considered the extent to which the independent variables collectively related to each wellbeing dimension. The independent variables accounted for $7 \%$ to $13 \%$ of the variance (adjusted $\mathrm{R}^{2}$ ). Table 4 reports the regression results, and Figure 1 (below) illustrates the size of the standardized multi-linear regression coefficients in the four independent regression models (one for each of the wellbeing dimensions). This allows us to compare the impact that a given variable (such as poor health) has independently on the wellbeing outcomes, adjusting for the extensive list of covariates.

Table 4. Multilinear regression analysis of (dichotomous) wellbeing variables (all coefficients are standardized)

\begin{tabular}{|c|c|c|c|c|}
\hline & \multicolumn{4}{|c|}{ Dependent variable: } \\
\hline & \multicolumn{4}{|c|}{ High Life Satisfaction Happiness Low Worry Eudaimoni } \\
\hline & (1) & (2) & (3) & (4) \\
\hline \multirow[t]{2}{*}{ isFemale } & $0.07^{* * *}$ & $0.02^{* * *}$ & $-0.02^{* * *}$ & $0.02^{* * *}$ \\
\hline & $(0.004)$ & $(0.003)$ & $(0.004)$ & $(0.005)$ \\
\hline \multirow[t]{2}{*}{ isOld } & $0.14^{* * *}$ & $0.02^{* * *}$ & $0.13^{* * *}$ & $0.09^{* * * *}$ \\
\hline & $(0.005)$ & $(0.003)$ & $(0.004)$ & $(0.005)$ \\
\hline \multirow[t]{2}{*}{ isMarried } & $0.07^{* * *}$ & $0.03^{* * *}$ & -0.004 & $0.02^{* * *}$ \\
\hline & $(0.01)$ & $(0.003)$ & $(0.005)$ & $(0.01)$ \\
\hline \multirow[t]{2}{*}{ isDivorced } & -0.01 & $-0.02^{* * *}$ & $-0.01^{*}$ & -0.01 \\
\hline & $(0.01)$ & $(0.005)$ & $(0.01)$ & $(0.01)$ \\
\hline \multirow[t]{2}{*}{ isHighIncome } & $0.09^{* * *}$ & 0.005 & 0.01 & $0.03^{* * *}$ \\
\hline & $(0.01)$ & $(0.003)$ & $(0.005)$ & $(0.01)$ \\
\hline \multirow[t]{2}{*}{ isLowIncome } & $-0.01^{* *}$ & $-0.04^{* * *}$ & $-0.05^{* * *}$ & $-0.01^{*}$ \\
\hline & $(0.01)$ & $(0.004)$ & $(0.01)$ & $(0.01)$ \\
\hline \multirow[t]{2}{*}{ isInsured } & $0.03^{* * *}$ & $0.01^{* *}$ & $0.03^{* * *}$ & $-0.02^{* *}$ \\
\hline & $(0.01)$ & $(0.005)$ & $(0.01)$ & $(0.01)$ \\
\hline \multirow[t]{2}{*}{ isGraduate } & $0.03^{* * *}$ & $-0.01^{* * *}$ & $-0.04^{* * *}$ & -0.002 \\
\hline & $(0.005)$ & $(0.003)$ & $(0.004)$ & $(0.005)$ \\
\hline \multirow[t]{2}{*}{ isExcellentHealth } & $0.10^{* * *}$ & $0.03^{* * *}$ & $0.04^{* * *}$ & $0.10^{* * *}$ \\
\hline & $(0.01)$ & $(0.004)$ & $(0.01)$ & $(0.01)$ \\
\hline \multirow[t]{2}{*}{ isPoorHealth } & $-0.12^{* * *}$ & $-0.13^{* * *}$ & $-0.12^{* * *}$ & $-0.09^{* * *}$ \\
\hline & $(0.01)$ & $(0.004)$ & $(0.01)$ & $(0.01)$ \\
\hline \multirow[t]{2}{*}{ isObese } & $-0.03^{* * *}$ & $0.01^{*}$ & $0.01^{* * *}$ & 0.01 \\
\hline & $(0.01)$ & $(0.003)$ & $(0.005)$ & $(0.01)$ \\
\hline \multirow[t]{2}{*}{ isDepressed } & $-0.08^{* * * *}$ & $-0.13^{* * *}$ & $-0.19^{* * *}$ & $-0.09^{* * *}$ \\
\hline & $(0.01)$ & $(0.004)$ & $(0.01)$ & $(0.01)$ \\
\hline \multirow[t]{2}{*}{ isExercise } & $0.05^{* * *}$ & $0.04^{* * *}$ & $0.04^{* * *}$ & $0.07^{* * *}$ \\
\hline & $(0.005)$ & $(0.003)$ & $(0.004)$ & $(0.005)$ \\
\hline \multirow[t]{2}{*}{ isVeggies } & $0.04^{* * *}$ & $0.04^{* * *}$ & $0.02^{* * *}$ & $0.07^{* * *}$ \\
\hline & $(0.005)$ & $(0.003)$ & $(0.004)$ & $(0.005)$ \\
\hline \multirow[t]{2}{*}{ isAlone } & $-0.02^{*}$ & $-0.15^{* * *}$ & $-0.03^{* * *}$ & $-0.03^{* * *}$ \\
\hline & $(0.01)$ & $(0.01)$ & $(0.01)$ & $(0.01)$ \\
\hline \multirow[t]{2}{*}{ isSmoker } & $-0.04^{* * * *}$ & $-0.03^{* * *}$ & $-0.02^{* * *}$ & -0.004 \\
\hline & $(0.01)$ & $(0.004)$ & $(0.01)$ & $(0.01)$ \\
\hline \multirow[t]{2}{*}{ isWeekendForLadder } & $0.01^{* *}$ & & & 0.001 \\
\hline & $(0.005)$ & & & $(0.005)$ \\
\hline \multirow[t]{2}{*}{ isWeekendForAffect } & & $0.03^{* * *}$ & $0.05^{* * *}$ & \\
\hline & & $(0.003)$ & $(0.004)$ & \\
\hline \multirow[t]{2}{*}{ Constant } & 0.00 & 0.00 & 0.00 & 0.00 \\
\hline & $(0.01)$ & $(0.01)$ & $(0.01)$ & $(0.01)$ \\
\hline Observations & 46,179 & 46,179 & 46,179 & 46,179 \\
\hline $\mathrm{R}^{2}$ & 0.13 & 0.10 & 0.11 & 0.07 \\
\hline Adjusted $\mathrm{R}^{2}$ & 0.13 & 0.10 & 0.11 & 0.07 \\
\hline Residual Std. Error $(\mathrm{df}=46161)$ & 0.47 & 0.29 & 0.43 & 0.48 \\
\hline F Statistic $(\mathrm{df}=17 ; 46161)$ & $412.09^{* * *}$ & $312.97^{* * *}$ & $330.10^{* * *}$ & $214.02^{* * *}$ \\
\hline
\end{tabular}


In general, health-related items, especially poor health and depression, were consistently the strongest correlates of the wellbeing items, with the strongest correlations between poor health and low happiness (positive affect), as well as between depression and worry (negative affect). Whereas both poor health and depression related to lower life satisfaction (evaluative wellbeing), depression was more strongly related to the affective domains (greater worry and lower happiness). Excellent health had stronger associations with evaluative wellbeing and eudaimonic wellbeing than with the affective dimensions. Older age was associated with higher life satisfaction, eudaimonic wellbeing and with less worry. Poor health was the only variable that seemed to cut across all wellbeing dimensions.
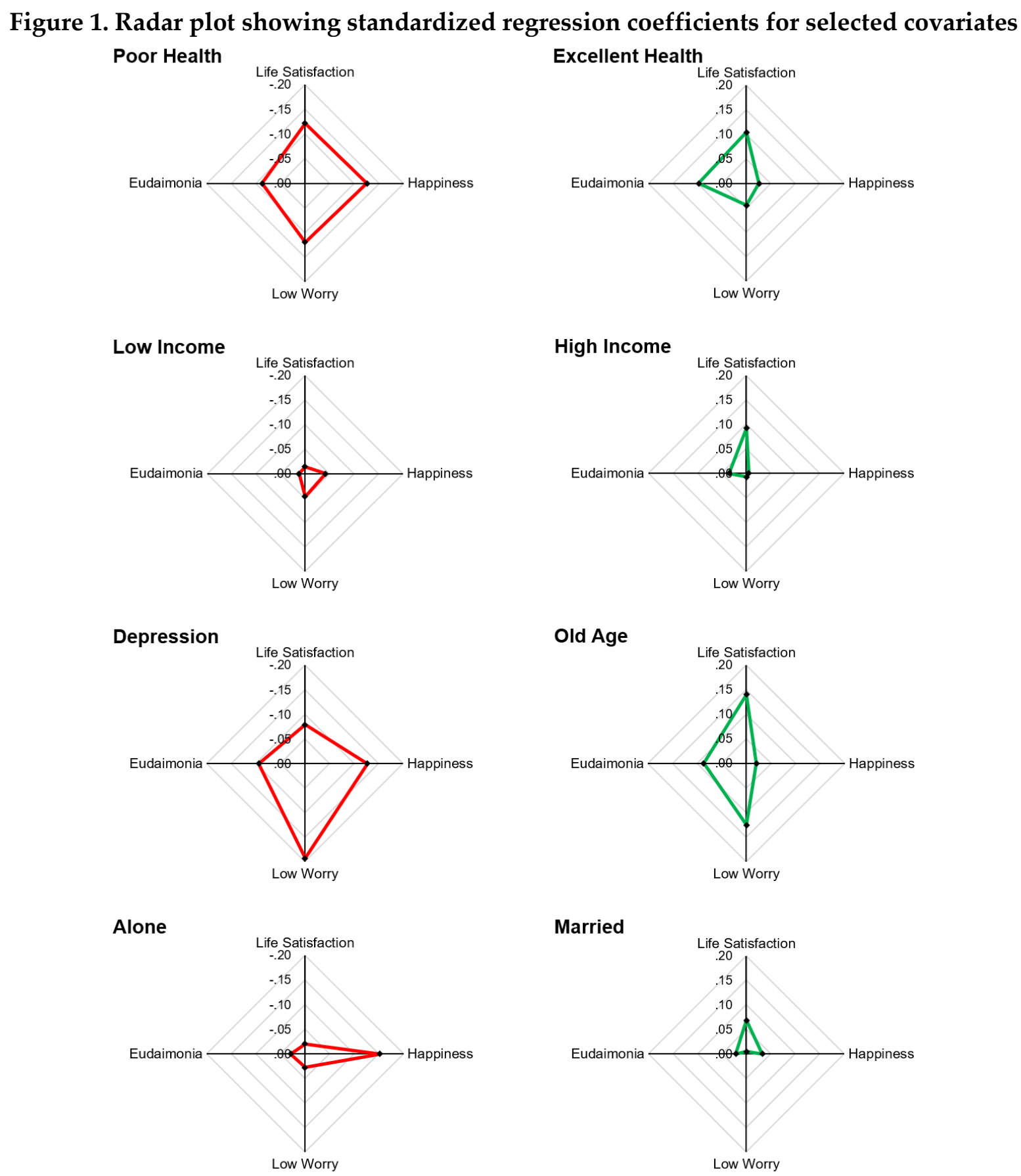

Note. (see Table 4 for full models). The corners of the rectangle reflect the coefficients that a given covariate (e.g., depression) had in the four 4 regression models for each wellbeing dimension. All covariates and 
wellbeing variables are dichotomous and all plots use the same scale $(0<|\beta|<.2$; thus, magnitudes are comparable). Red (left side) indicates negative undesirable) associations; green (right side) indicates positive (desirable) associations. The shape of the rectangles can be interpreted to reflect the specificity with which a given covariate affects a particular wellbeing dimension (for example, alone has a larger (negative) effect on happiness than on the other wellbeing dimensions).

For evaluative wellbeing (life satisfaction), the predictors explained $13 \%$ of the overall variance $(\mathrm{F}(17,46161)=412.09, p<.001)$. The strongest predictors of life satisfaction were older age $(\beta=$ $.14)$, excellent health $(\beta=.10)$, and high income $(\beta=.09)$. On the other hand, poor health $(\beta=-$ $.12)$, depression $(\beta=-.08)$, and smoking $(\beta=-.04)$ predicted lower levels of life satisfaction.

For affective wellbeing, the predictors explained $10 \%$ of the overall variance in positive affect (feeling happy; $\mathrm{F}(17 ; 46161)=312.97 ; p<.001)$, and $11 \%$ of the overall variance in negative affect (feeling worried; $\mathrm{F}(17 ; 46161)=330.10 ; \mathrm{p}<.001)$. Undesirable correlations with affect tended to be stronger than desirable ones. For positive affect, being alone $(\beta=-.15)$, depressed $(\beta=-.13)$ or in poor health $(\beta=-.13)$ predicted lower feelings of happiness. Similarly, depression $(\beta=-.19)$, poor health $(\beta=-.12)$, and low income $(\beta=-.05)$ predicted higher levels of worry, whereas older age ( $\beta$ $=.13$ ) predicted lower levels of worry. Beyond the small effects observed for the lifestyle factors of exercise and eating vegetables frequently $\left(\beta^{\prime} s=0.04\right)$, no variable predicted higher happiness with larger magnitudes.

For eudaimonic wellbeing (liking what you do each day and learning or doing something interesting each day), the predictors explained $7 \%$ of the overall variance $(\mathrm{F}(17 ; 46161)=214.02$; $p<.001)$. Excellent health $(\beta=.10)$, older age $(\beta=.09)$, exercise $(\beta=.07)$ and good diet $(\beta=.07)$ predicted greater eudaimonic wellbeing, whereas depression $(\beta=-.09)$ and poor health $(\beta=-.09)$ predicted lower eudaimonic wellbeing.

\subsection{Supplemental analyses: Satiation points and age}

As a supplemental analysis, we examined the mean levels of the four wellbeing dimensions as a function of the number of hours spent socializing, days with 30+ minutes of exercise, and days eating 5 or more servings of fruits and vegetables. As illustrated in Figures 2-4 (below), patterns vary both in terms of the predictor and the wellbeing dimension. For social time (Figure 2), the wellbeing dimensions showed similar patterns, with considerable boosts in wellbeing from 0 to 4 hours, and then diminishing marginal gains for additional social time. For exercise (Figure 3), while eudaimonic wellbeing demonstrated a linear increase, measures of affective wellbeing demonstrated non-linear relationships, with the peak benefit at four to six days, and then dropping at seven days a week. For fruits and vegetables (Figure 4), evaluative and affective wellbeing increased in a linear manner up to six days a week, with no additional benefits on day seven, whereas eudaimonic wellbeing again demonstrated a linear pattern. 
Figure 2. Mean levels of the four wellbeing dimensions as a function of hours spent socially
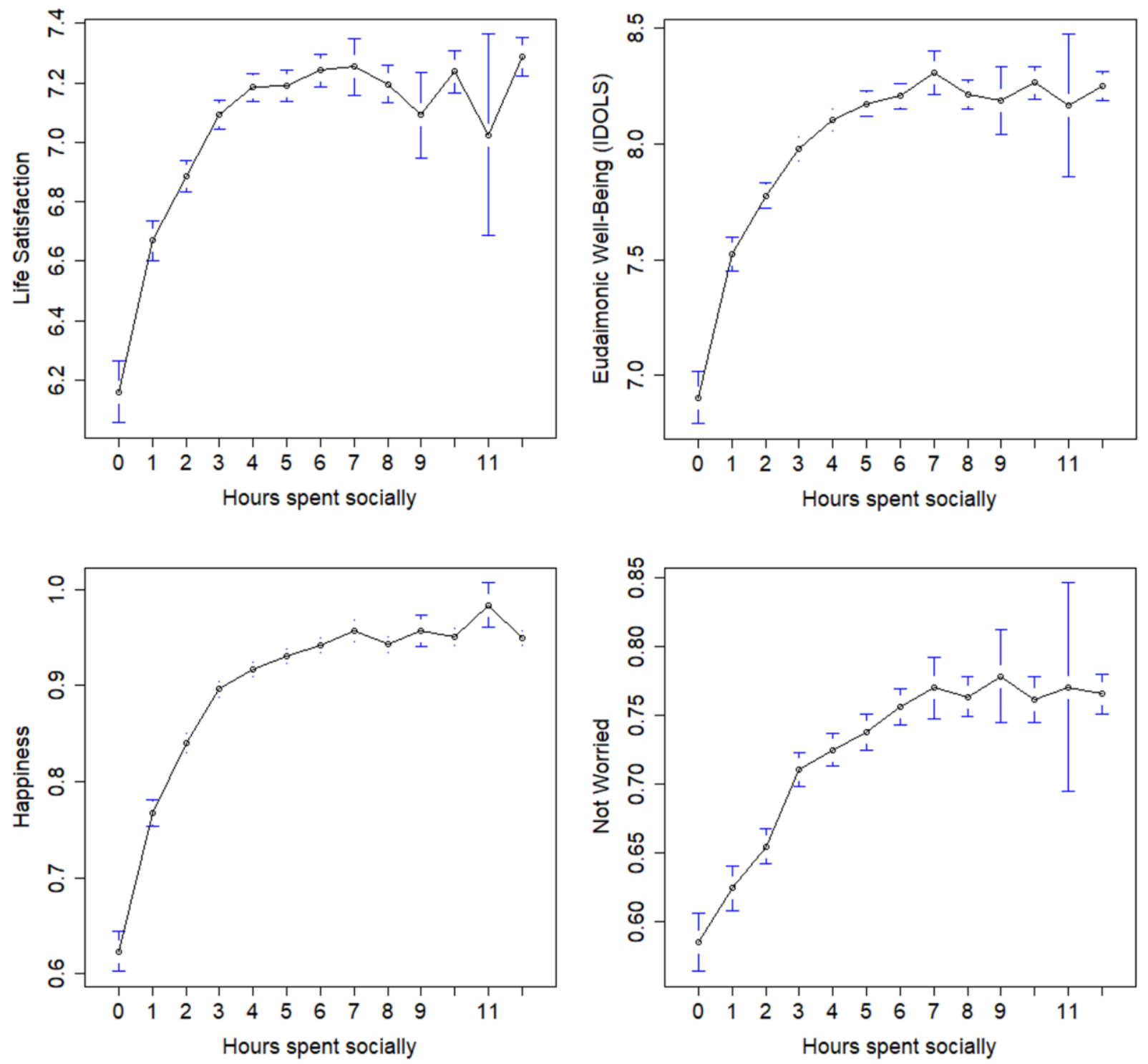

Note. Wellbeing dimensions: life satisfaction (evaluative), happiness (positive affective), not worried (low negative affective), and eudaimonic. 
Figure 3. Mean levels of the four wellbeing dimensions as a function of number of days with $30+$ mins of exercise
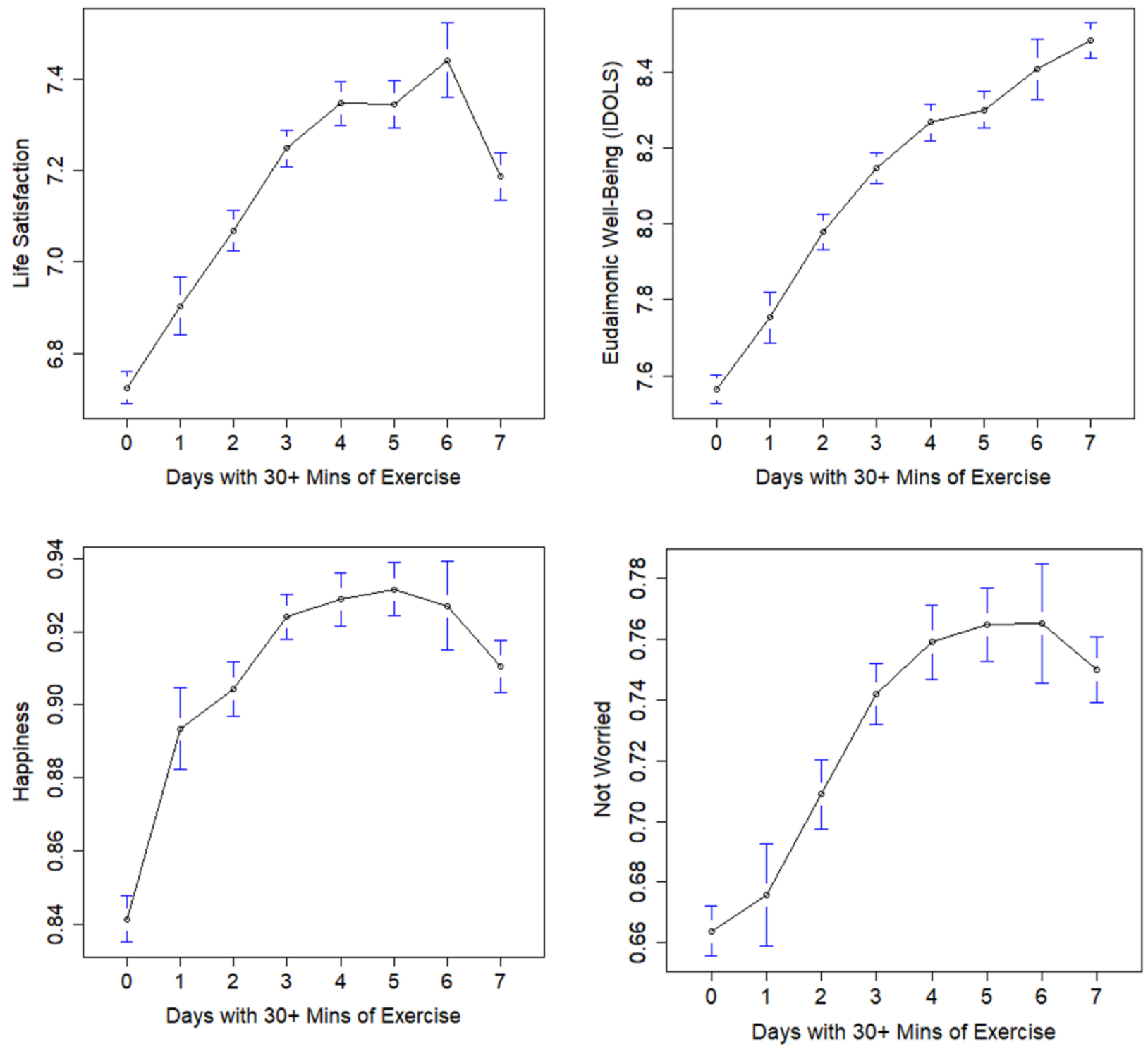

Note. Wellbeing dimensions: life satisfaction (evaluative), happiness (positive affective), not worried (low negative affective), and eudaimonic. 
Figure 4. Mean levels of the four wellbeing dimensions as a function of number of days with five servings of fruits \& vegetables
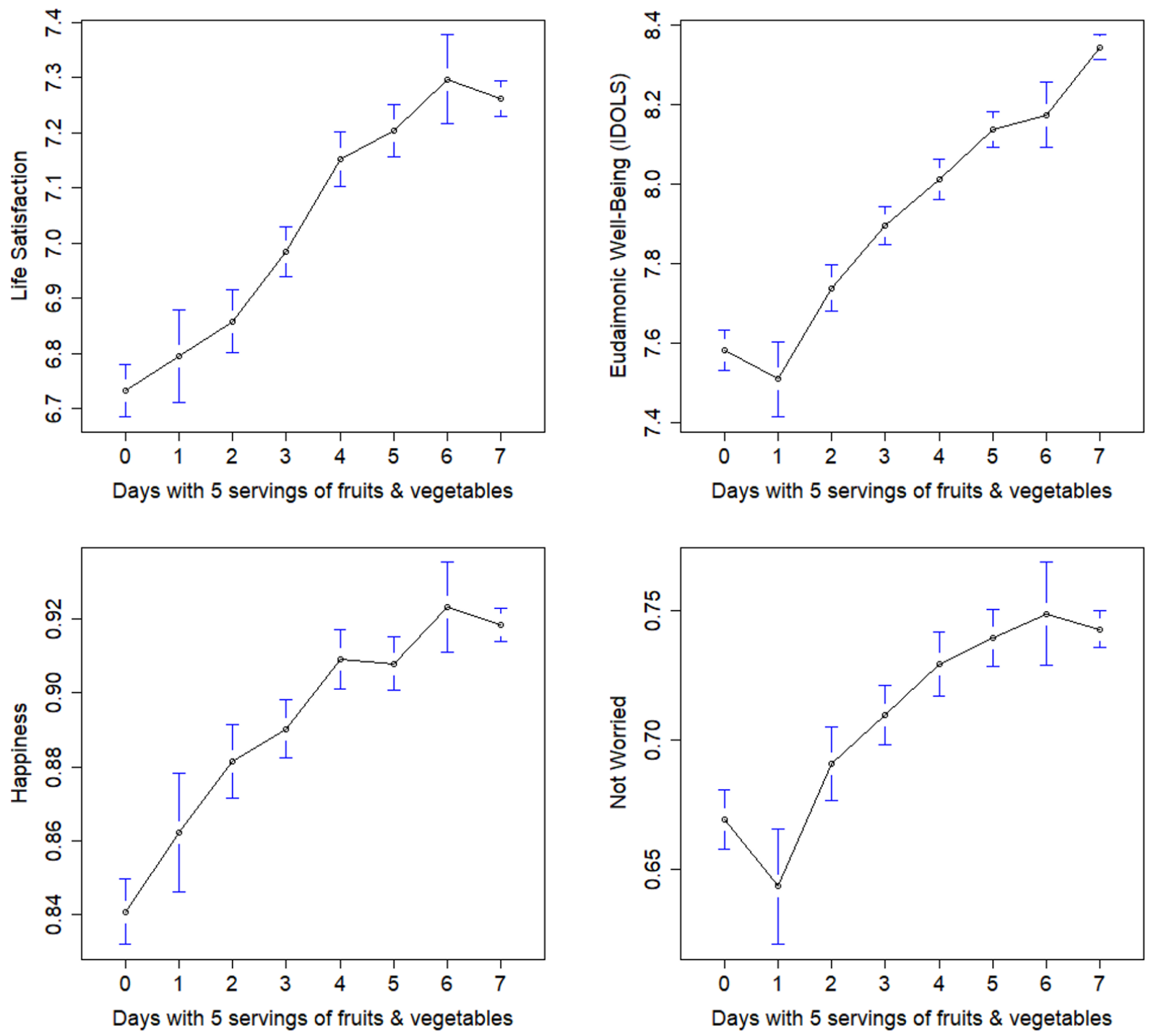

Note. Wellbeing dimensions: life satisfaction (evaluative), happiness (positive affective), not worried (low negative affective), and eudaimonic.

As seen in Figure 1 (above) and in the regressions (Table 4; above), old age emerged as the covariate with the strongest positive association with the wellbeing dimensions. To study this relationship further, we investigated how wellbeing changes as a function of age (based upon age groups within the cross-sectional dataset). Figure 5 (below) shows a clear increase in all four wellbeing dimensions around retirement age (60+). Conversely, across all four wellbeing dimensions, we observe evidence of the "midlife crisis", with lower levels of wellbeing at age 5055. In the case of happiness (positive affect), we observed a fairly linear downward trend from age 20 into middle age (lowest at 55 years) which reverses at age 65+. For life satisfaction and eudaimonic wellbeing, a weaker, secondary trend suggests a relative increase in wellbeing from the 20s into the 30s, which then roughly linearly decreases into the midlife low at age 50-55. 
Figure 5. Wellbeing dimensions as a function of age
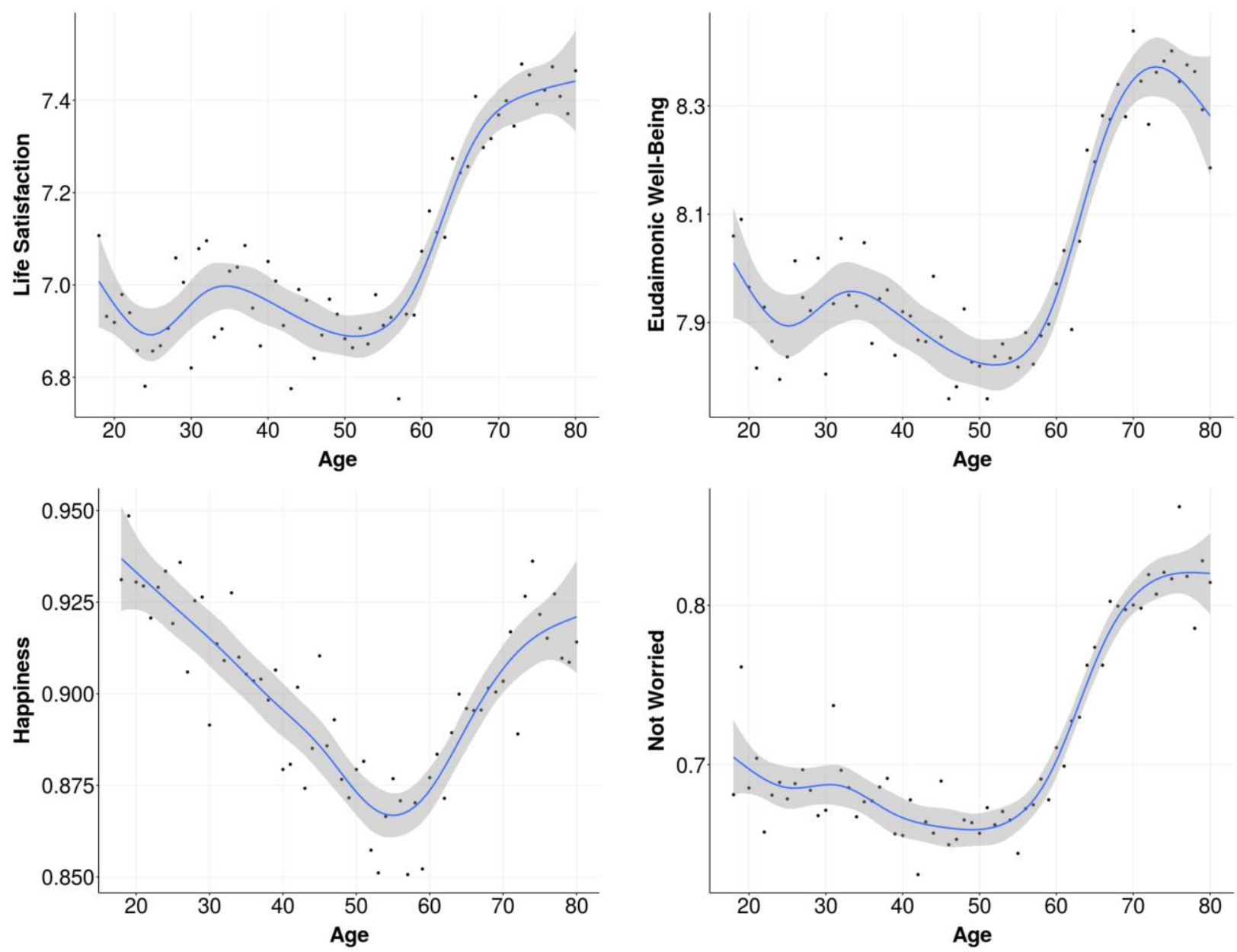

Note. Grey bands reflect $95 \%$ confidence intervals.

\section{Discussion}

Using a large sample from the Gallup-Healthways Wellbeing Index, we examined four dimensions of subjective mental wellbeing (evaluative, positive affective, negative affective, and eudaimonic) across a series of economic, demographic, health, and behavioral predictors. Our analyses resulted in two main findings. First, the four wellbeing dimensions only moderately correlated with one another and demonstrated distinctive patterns of correlates. As such, we recommend that future population surveys of wellbeing include these multiple dimensions. Second, when simultaneously adjusting for a wide range of demographic, economic, health, social and behavioral covariates, bad predictors-especially poor health and depressiondemonstrated stronger associations with (lower) wellbeing than did good predictors. Further, good predictors minimally related to positive affect, suggesting that positive emotions are easier lost than gained. This aligns with a review by Baumeister, Bratslavsky, Finkenauer, and Vohs (2001), which suggested bad events have more power than good ones.

\subsection{Differential patterns by wellbeing domain}

Our analyses revealed which wellbeing dimensions were influenced by a given covariate. For instance, high income was correlated with life satisfaction, but not the other wellbeing dimensions, whereas being alone was predominantly related to low positive affect. Similar to earlier results of the Berlin Aging Study (BASE), which found subjective health evaluation to be 
the strongest predictor of subjective wellbeing overall in old age (Smith, Borchelt, Maier, \& Jopp, 2002), we found health-related items as some of the strongest correlates of wellbeing outcomes. These results corroborate the dual relationship between physical health and subjective wellbeing observed by Friedman and Kern (2014) and Steptoe, Deaton, and Stone (2015). Aligned with other studies pointing to the importance of social relationships (e.g., Cacioppo, Hawkley, \& Bertson, 2003; Hawkley \& Cacioppo, 2010), being alone was one of the strongest negative predictors across dimensions.

Age. Older age was associated with higher evaluative wellbeing, lower negative affect, and higher eudaimonic wellbeing. Although well-studied, the relationship between wellbeing and age is equivocal (Horley \& Lavery, 1994). Some studies find that evaluative wellbeing tends to increase while positive affective wellbeing tends to decrease (Diener, Suh, Lucas, \& Smith, 1999; Smith et al., 2002; López Ulloa, Møller, \& Sousa-Poza, 2013). But there is also considerable variability in the aging experience (e.g., Baltes \& Baltes, 1990; Rowe \& Kahn, 1987). In our sample, older age related strongly to evaluative, (low) negative affective, and eudaimonic wellbeing dimensions, and was less relevant to positive affect, which was highest in young adulthood (age 20). This aligns with studies finding that high emotional aspects of wellbeing decrease with age, whereas lower arousal and eudaimonic components of wellbeing are more strongly associated with older ages (e.g., Carstensen \& Mikels, 2005; Carstensen, Pasupathy, Mayr, \& Nesselroade, 2000; Kern et al., 2014), pointing to the importance of considering multiple wellbeing dimensions.

The evidence we observed for midlife reductions in wellbeing reproduces previous work on a U-shaped wellbeing trajectory over the lifespan (Blanchflower \& Oswald, 2008; Orth, Robins, \& Widaman, 2012; Steptoe, Deaton, \& Stone, 2015; World Health Organization, 2015), a robust, well-replicated finding which has even been observed in non-human primates (Weiss, King, Inoue-Murayama, Matsuzawa, \& Oswald, 2012).

Income. Wellbeing research has given considerable focus to income as a primary marker of wellbeing (Diener \& Biswas-Diener, 2011; Futrelle, 2006). Evidence on the issue is mixed (Kahneman et al., 2006). While some authors claim that money cannot buy happiness (Spinella \& Lester, 2006), others find significant correlations between income and happiness, with effect sizes that vary between $r=.17$ and .21 (Lucas \& Dyrenforth, 2006). These roughly correspond to the correlations between (dichotomous) high income and (dichotomous) life satisfaction $(r=.16)$ and happiness $(r=.07)$ reported in the current study (see Table 3). Notably, in a German population, Lucas and Schimmack (2009) showed that small correlations between income and happiness translate into significant differences in life outcomes for people across different social strata. Deaton (2008) similarly found that higher levels of life satisfaction were associated with higher levels of log-transformed income.

Newer international data reveal that income is particularly important for the wellbeing of individuals who live in poverty and cannot meet their basic needs, and for individuals who live at the bottom of societies with high levels of income inequalities (Easterlin, 2013). Beyond an income threshold that varies across regions of the world, income does not seem to significantly increase wellbeing for wealthier individuals, does not yield higher wellbeing for wealthier countries, nor does it increase wellbeing for individuals or for countries as they become wealthier over time (Jebb, Tay, Diener, \& Oishi, 2018). Our results similarly suggest some benefit of income for the evaluative dimension, but not for other wellbeing dimensions. These newer data have significant implications for public policy regarding income distribution within and between countries.

Other covariates. Rubenstein and colleagues (2016) considered the association of demographic and economic variables with interpersonal, community, occupational, physical, psychological, 
and economic wellbeing dimensions, finding that demographic and economic variables showed associations of varying strengths with the wellbeing dimensions. We found a similar pattern of dimension-specific results, suggesting that demographic and economic variables affect some wellbeing dimensions more than others.

Public policy may benefit from targeting the variables that we identified through our analyses. For instance, the positive predictive power of health-related variables on wellbeing and the negative predictive power of negative health on wellbeing support policies that prioritise healthier living (Patton et al., 2016). Similarly, the positive predictive power of socializing and the negative predictive power of loneliness support a growing number of policies and initiatives targeting social isolation, particularly evident in individualistic societies and among the elderly (Holt-Lunstad, 2017). Our data underscore research demonstrating the importance of mental health interventions for depression and other mental health challenges (Layard, 2018; Marcus et al., 2012; Peasgood, Foster, \& Dolan, 2019). Our results also support studies that suggest that bad events or outcomes tend to have more consistent and larger effects than do positive ones for different variables (cf. Baumeister et al., 2001). For instance, previous studies show that dissatisfaction with social relationships generates more negative verbal and non-verbal communication than does satisfaction with relationships (Gotman, 1979, 1994), and poor or debilitating health is more detrimental to wellbeing than is good or excellent health (Easterlin, 2003; Mehnert, Krauss, Nadler, \& Boyd, 1990).

The different dimensions aligned with various threshold effects. Whereas four hours of socializing a day, four days with fruits and vegetables a week, and four days a week of exercise were associated with substantial benefits, there were diminishing returns beyond these points for the evaluative and positive and negative affective dimensions. This speaks to the value of relatively minor initial investments in these behaviors, along with the potential benefits of moderation. Policy messaging might provide these amounts as specific goals, rather than promoting a "more is always better" approach.

\subsection{Limitations}

Although we used a large dataset that is representative of the American population, care should be taken in generalizing to other cultures. The current US data does not capture nuances related to norms in other cultures, including differences in what individuals consider "ideal affect" (Tsai, Knutson, \& Fung, 2006). The items in our dataset may also fail to capture affective, eudaimonic, or evaluative wellbeing dimensions that are relevant in different cultural contexts. Extending the use of multiple dimensions of wellbeing in comparison with other variables across different cultures might reveal culturally specific models of wellbeing that prior research has identified (Oishi \& Gilbert, 2016), which may or may not align with the evaluative, affective, and eudaimonic dimensions that were used here.

Our dichotomous transformation and aggregation of data may generate discrepancies that make comparisons to studies using the ONS4 questions more difficult. For instance, we set up our eudaimonic component as the average of two Gallup questions that use different scales and wording when compared to the eudaimonic question from the Office for National Statistics. This was done in order to make more direct comparisons between measures of different response styles, but future data sets using continuous response options across each wellbeing measure would be preferable. Most Gallup questions had dichotomous response options, which reduces variability in the measures and attenuates effects.

Finally, our analysis is cross-sectional in nature, and although we selected wellbeing as dependent variables and the other variables as independent variables, the directional nature of 
such associations cannot be determined. Future studies might use small or large-scale interventional studies to establish the causal nature of these relationships.

\section{Conclusion}

The 2030 Sustainable Development Goals include "wellbeing for all people" (UN, 2015). To implement, evaluate, and refine policies aimed at increasing wellbeing, countries need multidimensional wellbeing indicators. Using a large nationally representative dataset, we considered four primary dimensions of subjective mental wellbeing: evaluative, positive affective, negative affective, and eudaimonic. Negative circumstances were more strongly related to decreases in each form of wellbeing than positive circumstances related to increases in wellbeing. Additionally, our findings point to the importance of including multiple dimensions of wellbeing in national surveys, with both positive and negative components, as economic, behavioral and social predictors show differentiated patterns of associations across these dimensions. Finally, lifestyle behaviors such as diet, exercising, and socializing show the strongest returns for initial investments of time and energy.

\section{Acknowledgements}

We thank the anonymous reviewers for their helpful suggestions and edits.

\section{Conflict of interest statement}

The authors report no conflicts of interest.

\section{Authors}

Johannes C. Eichstaedt

Stanford University

johannes.stanford@gmail.com

David B. Yaden

Johns Hopkins Medicine

Fernando M. Ribeiro

University of Pennsylvania

Alejandro Adler

Columbia University

Margaret L. Kern

University of Melbourne

Publishing Timeline

Received 11 January 2019

Revised submission received 4 July 2020

Accepted 21 July 2020

Published 30 September 2020

\section{References}

Adler, A. (2009). Gross national happiness in Bhutan: A living example of an alternative approach to progress. Social Impact Research Experience Journal, 33-38. 
Adler, A., \& Seligman, M. E. (2016). Using wellbeing for public policy: Theory, measurement, and recommendations. International Journal of Wellbeing, 6(1), 1-35. https://doi.org/10.5502/ijw.v6i1.429

Anderson, M., \& Mossialos, E. (2019). Beyond gross domestic product for New Zealand's wellbeing budget. The Lancet Public Health, 4(7), e320-e321. https://doi.org/10.1016/S2468-2667(19)30109-4

Baumeister, R. F., Bratslavsky, E., Finkenauer, C., \& Vohs, K. D. (2001). Bad is stronger than good. Review of General Psychology, 5(4), 323-370. https://doi.org/10.1037//1089-2680.5.4.323

Baumeister, R. F., Vohs, K. D., Aaker, J. L., \& Garbinsky, E. N. (2013). Some key differences between a happy life and a meaningful life. The Journal of Positive Psychology, 8, 505-516. https://doi.org/10.1080/17439760.2013.830764

Baumgartner, H., \& Steenkamp, J. (2001). Response styles in marketing research: A crossnational investigation. Journal of Marketing Research, 38, 143-156. https://doi.org/10.1509/jmkr.38.2.143.18840

Behrendt, S. (2014). Standardized regression coefficients to lm-objects [R Package]. Retrieved from https://cran.r-project.org/web/packages/lm.beta/lm.beta.pdf.

Bergheim, S. (2006). Measures of well-being. There is more to it than GDP. Retrieved from Deutsche Bank Research website: http://www.dbresearch.com/PROD/DBR_INTERNET_ENPROD/PROD0000000000202587.PDF

Bradburn, N. M. (1969). The structure of psychological well-being. Chicago: Walter de Gruyter.

Brickman, P., Coates, D., \& Janoff-Bulman, R. (1978). Lottery winners and accident victims: Is happiness relative? Journal of Personality and Social Psychology, 36(8), 917-927. https://doi.org/10.1037/00223514.36.8.917

Cacioppo, J. T., Hawkley, L. C., \& Berston, G. G. (2003). The anatomy of loneliness. Current Directions in Psychological Science, 12, 71-74. https://doi.org/10.1111/1467-8721.01232

Cantril, H. (1965). The pattern of human concerns. New Brunswick, NJ: Rutgers University Press.

Carstensen, L. L., \& Mikels, J. A. (2005). At the intersection of emotion and cognition: Aging and the positivity effect. Current Directions in Psychological Science, 14, 117-121. https://doi.org/10.1111/j.09637214.2005.00348.x

Carstensen, L. L., Pasupathi, M., Mayr, U., \& Nesselroade, J. R. (2000). Emotional experience in everyday life across the adult life span. Journal of Personality and Social Psychology, 79, 644-655. https://doi.org/10.1037/0022-3514.79.4.644

Chandler, J. (2016). A study to explore the impact of working in a social enterprise on employee health and wellbeing in Greater Manchester (Doctoral dissertation, University of Salford, Salford, United Kingdom). Retrieved from http://usir.salford.ac.uk/40753/1/THESIS\%20FINAL.pdf

Chanfreau, J., Lloyd, C., Byron, C., Roberts, C., Craig, R., Feo, D., \& McManus, S. (2013). Predicting wellbeing. Retrieved from NatCen Social Research/Department of Health website: http://natcen.ac.uk/media/205352/predictors-of-wellbeing.pdf

Chapman, D. P., \& Perry, G. S. (2008). Depression as a major component of public health for older adults. Preventing Chronic Disease, 5(1), 1-9. Retrieved from http://www.cdc.gov/pcd/issues/2008/jan/07_0150.htm.

Chattopadhyay, S. (2016). What gets measured, gets managed: Challenges ahead for UN's data-driven development agenda. Retrieved from Overseas Development Institute (ODI) website: https://www.odi.org/publications/10692-what-gets-measured-gets-managed-challenges-ahead-un-sdata-driven-development-agenda

Chia, A., Kern, M. L., \& Neville, B. A. (2020). CSR for happiness: Corporate determinants of societal happiness as social responsibility. Business Ethics. https://doi.org/10.1111/beer.12274

Clark, A. E., Diener, E., Georgellis, Y., \& Lucas, R. E. (2008). Lags and leads in life satisfaction: A test of the baseline hypothesis. The Economic Journal, 118(529), F222-F243. https://doi.org/10.1111/j.14680297.2008.02150.x

Collins, B. (2016). How do we value wellbeing? Combining data to put an economic value on the change in Short Warwick Edinburgh Wellbeing Scale (SWEMWBS) scores. SSRN Electronic Journal, 1-7. Retrieved from https://ssrn.com/abstract=2869251. https://doi.org/10.2139/ssrn.2869251 
Costanza, R., Daly, L., Fioramonti, L., Giovannini, E., Kubiszewski, I., Mortensen, L. F., ... \& Wilkinson, R. (2016). Modelling and measuring sustainable wellbeing in connection with the UN Sustainable Development Goals. Ecological Economics, 130, 350-355. https://doi.org/10.1016/j.ecolecon.2016.07.009

Csikszentmihalyi, M. (1999). If we are so rich, why aren't we happy? American Psychologist, 54(10), 821827. https://doi.org/10.1037//0003-066x.54.10.821

Davies, J. E. (2002). What gets measured, gets managed: statistics and performance indicators for evidence based management. Journal of Librarianship and Information Science, 34(3), 129-134. https://doi.org/10.1177/096100002401010727

Deaton, A. (2008). Income, Health, and Well-Being around the World: Evidence from the Gallup World Poll. Journal of Economic Perspectives, 22(2), 53-72. https://doi.org/10.1257/jep.22.2.53

Diener, E. (2000). Subjective well-being: The science of happiness and a proposal for a national index. American Psychologist, 55(1), 34-43. https://doi.org/10.1037//0003-066x.55.1.34

Diener, E., Lucas, R. E., \& Oishi, S. (2002). Subjective well-being: The science of happiness and life satisfaction. In C. R. Snyder \& S. J. Lopez (Eds.), Handbook of Positive Psychology. Oxford: Oxford University Press. https://doi.org/10.1093/oxfordhb/9780199734610.013.0029.

Diener, E. (2006). Guidelines for national indicators of subjective well-being and ill-being. Applied Research in Quality of Life, 1(2), 151-157. https://doi.org/10.1007/s11482-006-9007-x

Diener, E., \& Biswas-Diener, R. (2011). Happiness: Unlocking the mysteries of psychological wealth [Kindle]. Retrieved from https://www.amazon.com/Happiness-Unlocking-Mysteries-Psychological-Wealthebook/dp/B002LZULNI/ref=sr_1_1?s=digital-text\&ie=UTF8\&qid=1500396131\&sr=1$1 \&$ keywords=happiness+unlocking

Diener, E., Emmons, R. A., Larsen, R. J., \& Griffin, S. (1985). The satisfaction with life scale. Journal of Personality Assessment, 49(1), 71-75. https://doi.org/10.1207/s15327752jpa4901_13

Diener, E., Heintzelman, S. J., Kushlev, K., Tay, L., Wirtz, D., Lutes, L. D., \& Oishi, S. (2017). Findings all psychologists should know from the new science on subjective well-being. Canadian Psychology/Psychologie canadienne, 58(2), 87-104. https://doi.org/10.1037/cap0000063

Diener, E., Inglehart, R., \& Tay, L. (2012). Theory and validity of life satisfaction scales. Social Indicators Research, 112, 497-527. https://doi.org/10.1007/s11205-012-0076-y

Diener, E., Lucas, R. E., \& Scollon, C. N. (2006). Beyond the hedonic treadmill: Revising the adaptation theory of well-being. American Psychologist, 61(4), 305-314. https://doi.org/10.1037/0003-066x.61.4.

Diener, E., Lucas, R. E., \& Oishi, S. (2002). Subjective well-being: Th e science of happiness and life satisfaction. In C. R. Snyder, \& S. J. Lopez (Eds.), The handbook of positive psychology (pp. 63-73). New York: Oxford University Press

Diener, E., Lucas, R., \& Oishi, S. (2009). Subjective well-being: The science of happiness and life satisfaction. Oxford Handbooks Online. https://doi.org/10.1093/oxfordhb/9780195187243.013.0017

Diener, E., Oishi, S., \& Lucas, R. (2015). National accounts of subjective well-being. American Psychological Association, 70(3), 234-242. https://doi.org/10.1037/a0038899

Diener, E., \& Seligman, M. E. (2004). Beyond money: Toward an economy of well-being. Psychological Science in the Public Interest, 5(1), 1-31. https://doi.org/10.1111/j.0963-7214.2004.00501001.x

Diener, E., Suh, E. M., Lucas, R. E., \& Smith, H. L. (1999). Subjective well-being: Three decades of progress. Psychological Bulletin, 125(2), 276-302. https://doi.org/10.1037//0033-2909.125.2.276

Diner, E. \& Suh, E. M. (2016). National differences in subjective well-being. In D. Kahneman; E. Diener; \& N. Schwarz (Eds.), Well-Being: Foundations of Hedonic Psychology (pp. 434-450). [Adobe PDF]. https://muse.jhu.edu/book/15017

Dolan, P., Layard, R., \& Metcalfe, R. (2011). Measuring subjective well-being for public policy. Retrieved from Office for National Statistics website: https://www.ons.gov.uk/ons/guide-method/userguidance/well-being/publications/measuring-subjective-well-being-for-public-policy.pdf

Dolan, P., \& Metcalfe, R. (2012). Measuring subjective wellbeing: Recommendations on measures for use by national governments. Journal of Social Policy, 41(02), 409-427. https://doi.org/10.1017/s0047279411000833

Durand, M. (2018). Countries' experiences with well-being and happiness metrics. Global Happiness. 
Durand, M., \& Exton, C. (2019). Adopting a well-being approach in central government: Policy mechanisms and practical tools. Global Happiness and Wellbeing.

Easterlin, R. A. (2003). Explaining happiness. Proceedings of the National Academy of Sciences, 100(19), 11176-11183. https://doi.org/10.1073/pnas.1633144100

Easterlin, R. A., \& Angelescu, L. (2009). Happiness and growth the world over: Time series evidence on the happiness-income paradox (4060). Retrieved from IZA website: https://www.econstor.eu/bitstream/10419/35652/1/597845883.pdf

Easterlin, R. A., \& Sawangfa, O. (2010). Happiness and economic growth: Does the cross section predict time trends? Evidence from developing countries. International Differences in Well-Being, 166-216. https://doi.org/10.1093/acprof:oso/9780199732739.003.0007

Easterlin, R. A., McVey, L. A., Switek, M., Sawangfa, O., \& Zweig, J. S. (2010). The happiness-income paradox revisited. Proceedings of the National Academy of Sciences, 107(52), 22463-22468. https://doi.org/10.1073/pnas.1015962107

Easterlin, R. A. (2013). Happiness, growth, and public policy. Economic Inquiry, 51(1), 1-15. https://doi.org/10.1111/j.1465-7295.2012.00505.x

Eichstaedt, J. C., Schwartz, H. A., Kern, M. L., Park, G., Labarthe, D. R., Merchant, R. M., ... \& Weeg, C. (2015). Psychological language on Twitter predicts county-level heart disease mortality. Psychological Science, 26(2), 159-169. https://doi.org/10.1177/0956797614557867

Fischer, R., \& Boer, D. (2011). What is more important for national well-being: Money or autonomy? A meta-analysis of well-being, burnout, and anxiety across 63 societies. Journal of Personality and Social Psychology, 101(1), 164-184. https://doi.org/10.1037/a0023663

Fox, J. (2012, February). The economics of well-being. Harvard Business Review. Retrieved from https://hbr.org/2012/01/the-economics-of-well-being

Friedman, H. S., \& Kern, M. L. (2014). Personality, health, and well-being. Annual Review of Psychology, 65, 719-742. https://doi.org/10.1146/annurev-psych-010213-115123

Frisch, M. B., Cornell, J., Villanueva, M., \& Retzlaff, P. J. (1992). Clinical validation of the Quality of Life Inventory. A measure of life satisfaction for use in treatment planning and outcome assessment. Psychological Assessment, 4(1), 92-101. https://doi.org/10.1037//1040-3590.4.1.92

Futrelle, D. (2006, July). Can money buy happiness? Of course not! Or can it? Surprising new research sheds light on how you can (and can't) spend your way to a sunnier outlook on life. Money Magazine, 35(8). Retrieved from http://micro.borisnikolaev.com/files/Can\%20Money\%20Buy\%20Happiness.pdf

Gallup. (2016). How does Gallup daily tracking work? Retrieved from http://www.gallup.com/174155/gallup-daily-tracking-methodology.aspx

Gallup. (2018). Gallup-Sharecare well-being index. Retrieved December 2, 2018, from http://www.gallup.com/poll/106756/galluphealthways-wellbeing-index.aspx

Goodman, F. R., Disabato, D. J., Kashdan, T. B., \& Kauffman, S. B. (2018). Measuring well-being: A comparison of subjective well-being and PERMA. The Journal of Positive Psychology, 13(4), 321-332. https://doi.org/10.1080/17439760.2017.1388434

Guntuku, S. C., Yaden, D. B., Kern, M. L., Ungar, L. H., \& Eichstaedt, J. C. (2017). Detecting depression and mental illness on social media: an integrative review. Current Opinion in Behavioral Sciences, 18, 43-49. https://doi.org/10.1016/j.cobeha.2017.07.005

Heine, S. J., Lehman, D. R., Peng, K., \& Greenholtz, J. (2002). What's wrong with cross-cultural comparisons of subjective likert scales?: The reference group effect. Journal of Personality and Social Psychology, 82, 903-918. https://doi.org/10.1037//0022-3514.82.6.903

Hawkley, L. C., \& Cacioppo, J. T., (2010). Loneliness matters: A theoretical and empirical review of consequences and mechanisms. Annals of Behavioral Medicine, 40, 218-227. https://doi.org/10.1007/s12160-010-9210-8

Helliwell, J. F., \& Aknin, L. B. (2018). Expanding the social science of happiness. Nature Human Behaviour, 2, 248-252. https://doi.org/10.1038/s41562-018-0308-5

Helliwell, J. F., \& Barrington-Leigh, C. P. (2010). Measuring and understanding subjective well-being. Canadian Journal of Economics, 43, 729-753. https://doi.org/10.1111/j.1540-5982.2010.01592.x 
Helliwell, J. F., Huang, H., \& Wang, S. (2017). Social foundations of world happiness. In J. Helliwell, R. Layard, and J. Sachs (Eds.), World happiness report 2017 (pp. 8-47). New York: Sustainable Development Solutions Network.

Holt-Lunstad, J. (2017). The potential public health relevance of social isolation and loneliness: Prevalence, epidemiology, and risk factors. Public Policy E Aging Report, 27(4), 127-130. https://doi.org/10.1093/ppar/prx030

Horley, J., \& Lavery, J. J. (1995). Subjective well-being and age. Social Indicators Research, 34(2), 275-282. https://doi.org/10.1007/bf01079200

Hornsey, M. J., Bain, P. G., Harris, E. A., Lebedeva, N., Kashima, E. S., Guan, Y., ..., Blumen, S. (2018). How much is enough in a perfect world? Cultural variation in ideal levels of happiness, pleasure, freedom, health, self-esteem, longevity, and intelligence. Psychological Science, 29, 1393-1404. https://doi.org/10.1177/0956797618768058

Huta, V., \& Waterman, A. S. (2013). Eudaimonia and its distinction from hedonia: Developing a classification and terminology for understanding conceptual and operational definitions. Journal of Happiness Studies, 15(6), 1425-1456. https://doi.org/10.1007/s10902-013-9485-0

Izutsu, T., Tsutsumi, A., Minas, H., Thornicroft, G., Patel, V., \& Ito, A. (2015). Mental health and wellbeing in the Sustainable Development Goals. The Lancet Psychiatry, 2(12), 1052-1054. https://doi.org/10.1016/S2215-0366(15)00457-5

Jaidka, K., Giorgi, S., Schwartz, H. A., Kern, M. L., Ungar, L. H., \& Eichstaedt, J. C. (2020). Estimating geographic subjective well-being from Twitter: A comparison of dictionary and data-driven language methods. Proceedings of the National Academy of Sciences, 117(19), 10165-10171. https://doi.org/10.1073/pnas.1906364117

Jebb, A. T., Tay, L., Diener, E., \& Oishi, S. (2018). Happiness, income satiation and turning points around the world. Nature Human Behaviour, 2(1), 33-38. https://doi.org/10.1038/s41562-017-0277-0

Joshanloo, M. (2019). Structural and discriminant validity of the tripartite model of mental well-being: differential relationships with the big five traits, Journal of Mental Health, 28, 168-174. https://doi.org/10.1080/09638237.2017.1370633

Joshanloo, M., \& Weijers, D. (2019). A two-dimensional conceptual framework for understanding mental well-being. PloS one, 14(3), e0214045. https://doi.org/10.1371/journal.pone.0214045

Kahneman, D., Schkade, D. A., Fischler, C., Krueger, A. B., \& Krilla, A. (2010). The structure of well-being in two cities: Life satisfaction and experienced happiness in Columbus, Ohio; and Rennes, France. International differences in well-being, 16-33. https://doi.org/10.1093/acprof:oso/9780199732739.003.0002

Kahneman, D. (1999). Objective happiness. In D. Kahneman; E. Diener; \& N. Schwarz (Eds.), Well-Being: Foundations of Hedonic Psychology (pp. 3-25). [Adobe PDF].

Kahneman, D. (2015). Thinking, fast and slow [Kindle]. Retrieved from https://www.amazon.com/Thinking-Fast-Slow-Daniel-Kahnemanebook/dp/B00555X8OA/ref=sr_1_1_ha?s=digital-text\&ie=UTF8\&qid=1498763342\&sr=1$1 \&$ keywords=thinking+fast+and+slow

Kahneman, D., \& Deaton, A. (2010). High income improves evaluation of life but not emotional wellbeing. Proceedings of the National Academy of Sciences, 107(38), 16489-16493. https://doi.org/10.1073/pnas.1011492107

Kahneman, D., Krueger, A. B., Schkade, D., Schwarz, N., \& Stone, A. A. (2006). Would you be happier if you were richer? A focusing illusion. Science, 312(5782), 1908-1910. https://doi.org/10.1126/science.1129688

Kapteyn, A., Lee, J., Tassot, C., Vonkova, H., \& Zamarro, G. (2015). Dimensions of subjective well-being. Social Indicators Research, 123, 625-660. https://doi.org/10.1007/s11205-014-0753-0

Kennedy, R. F. (1968, March 18). Robert F. Kennedy speeches: Remarks at the University of Kansas. John F. Kennedy Presidential Library and Museum. Retrieved from https://www.jfklibrary.org/Research/Research-Aids/Ready-Reference/RFK-Speeches/Remarks-ofRobert-F-Kennedy-at-the-University-of-Kansas-March-18-1968.aspx 
Kern, M. L., Eichstaedt, J. C., Schwartz, H. A., Park, G., Ungar, L. H., Stillwell, D. J., .. \& Seligman, M. E. P. (2014). From "sooo excited!!!" to "so proud": Using language to study development. Developmental Psychology, 50, 178-188. https://doi.org/10.1037/a0035048

Kern, M. L., Waters, L., White, M., \& Adler, A. (2014). Assessing employee wellbeing in schools using a multifaceted approach: Associations with physical health, life satisfaction, and professional thriving. Psychology, 5, 500-513. https://doi.org/10.4236/psych.2014.56060

Kern, M. L., Zeng, G., Hou, H., \& Peng, K. (in press). The Chinese version of the EPOCH Measure of Adolescent Wellbeing: Testing cross-cultural measurement invariance. Journal of Psychoeducational Assessment.

Keyes, C. L. (2002). The mental health continuum: From languishing to flourishing in life. Journal of Health and Social Behavior, 43(2), 207-222. https://doi.org/10.2307/3090197

Lawless, N. M., \& Lucas, R. E. (2011). Predictors of regional well-being: A county level analysis. Social Indicators Research, 101(3), 341-357. https://doi.org/10.1007/s11205-010-9667-7

Layard, R. (2010). Measuring subjective well-being. Science, 327(5965), 534-535. https://doi.org/10.1126/science.1186315

Layard, R. (2018). Mental illness destroys happiness and is costless to treat. Global Happiness Policy Report, 63, 19-31.

López Ulloa, B. F., Møller, V., \& Sousa-Poza, A. (2013). How does subjective well-being evolve with age? A literature review. Journal of Population Ageing, 6(3), 227-246. https://doi.org/10.1007/s12062-0139085-0

Lucas, R. E., \& Dyrenforth, P. S. (2006). Does the existence of social relationships matter for subjective well-being? In K. D. Vohls \&E. J. Finkel (Eds.), Self and relationships: Connecting intrapersonal and interpersonal processes (pp. 254-273). [Adobe PDF].

Lucas, R. E., \& Schimmack, U. (2009). Income and well-being: How big is the gap between the rich and the poor? Journal of Research in Personality, 43(1), 75-78. https://doi.org/10.1016/j.jrp.2008.09.004

Luhmann, M., Hofmann, W., Eid, M., \& Lucas, R. E. (2012). Subjective well-being and adaptation to life events: A meta-analysis. Journal of Personality and Social Psychology, 102(3), 592-615. https://doi.org/10.1037/a0025948

Lyubomirsky, S., Sheldon, K. M., \& Schkade, D. (2005). Pursuing happiness: The architecture of sustainable change. Review of General Psychology, 9(2), 111-131. https://doi.org/10.1037/10892680.9.2.111

Maddux, J. E. (2012). Self-efficacy: The power of believing you can. In S. J. Lopez \& C. R. Snyder, The Oxford Handbook of Positive Psychology (2 ed., pp. 277-287). https://doi.org/10.1093/oxfordhb/9780195187243.013.0031

Marcus, M., Yasamy, M. T., van Ommeren, M. V., Chisholm, D., \& Saxena, S. (2012). Depression: A global public health concern. World Federation of Mental health, WHO. https://doi.org/10.1037/e517532013004

Marsh, A., Smith, L., Piek, J., \& Saunders, B. (2003). The Purpose in Life Scale: Psychometric properties for social drinkers and drinkers in alcohol treatment. Educational and Psychological Measurement, 63(5), 859-871. https://doi.org/10.1177/0013164403251040

Maslow, A. H. (1943). A theory of human motivation. Psychological Review, 50, 370-396. https://doi.org/10.1037/h0054346

McQuaid, M., \& Kern, M. L. (2017). Your wellbeing blueprint: Feeling good and doing well at work. Victoria, Australia: McQuaid Ltd.

Mehnert, T., Krauss, H. H., Nadler, R., \& Boyd, M. (1990). Correlates of life satisfaction in those with disabling conditions. Rehabilitation Psychology, 35(1), 3-17. https://doi.org/10.1037//0090-5550.35.1.3

Melchert, N. (2002). Aristotle: The reality of the world. The good life. In The great conversation: A historical introduction to philosophy (4 ed., pp. 186-198). Boston, MA: McGraw-Hill

OECD. (2013). OECD guidelines on measuring subjective well-being. OECD Publishing, 139-178. https://doi.org/10.1787/978926419165 5-en

OECD (2020), How's Life? 2020: Measuring Well-being, OECD Publishing, Paris, https://doi.org/10.1787/9870c393-en. 
Oishi, S., Schimmack, U., \& Diener, E. (2012). Progressive taxation and the subjective well-being of nations. Psychological Science, 23, 86-92. https://doi.org/10.1177/0956797611420882

Oishi, S., \& Gilbert, E. A. (2016). Current and future directions in culture and happiness research. Current Opinion in Psychology, 8, 54-58. https://doi.org/10.1016/j.copsyc.2015.10.005

Office for National Statistics (2011) Measuring Subjective Well-being.

Office for National Statistics (2015) Measuring National Well-being, Personal Well-being in the UK, Three Year Data 2011/2014.

ONS. (2016). Personal well-being in the UK: Quality and methodology information. Retrieved from Office for National Statistics website:

https://www.ons.gov.uk/peoplepopulationandcommunity/wellbeing/qmis/subjectivewellbeingannu alpopulationsurveyapsqmi

OPHI. (n.d.). Bhutan's gross national happiness index. Retrieved from http://www.ophi.org.uk/policy/national-policy/gross-national-happiness-index/

Orth, U., Robins, R. W., \& Widaman, K. F. (2012). Life-span development of self-esteem and its effects on important life outcomes. Journal of Personality and Social Psychology, 102(6), 1271-1288. https://doi.org/10.1037/a0025558

Patton, G. C., Sawyer, S. M., Santelli, J. S., Ross, D. A., Afifi, R., Allen, N. B., ... \& Kakuma, R. (2016). Our future: A Lancet commission on adolescent health and wellbeing. The Lancet, 387(10036), 2423-2478. https://doi.org/10.1016/S0140-6736(16)00579-1

Peasgood, T., Foster, D., \& Dolan, P. (2019). Priority setting in healthcare through the lens of happiness. Global Happiness and Well-Being Policy Report.

Perovic, L. M., \& Golem, S. (2010). Investigating macroeconomic determinants of happiness in transition countries. Eastern European Economics, 48(4), 59-75. https://doi.org/10.2753/eee0012-8775480403

Prilleltensky, I., Dietz, S., Prilleltensky, O., Myers, N. D., Rubenstein, C. L., Jin, Y., \& McMahon, A. (2015). assessing multidimensional well-being: development and validation of the I COPPE scale. Journal of Community Psychology, 43(2), 199-226. https://doi.org/10.1002/jcop.21674

Reyes-Garcia, V., Babigumira2, R., Pyhala, A., Wunder, S., Zorondo-Rodriguez, F., \& Angelsen, A. (2016). Subjective wellbeing and income: Empirical patterns in the rural developing world. Journal of Happiness Studies, 17(2), 773-791. https://doi.org/10.1007/s10902-014-9608-2

Rubenstein, C. L., Duff, J., Prilleltensky, I., Jin, Y., Dietz, S., Myers, N. D., \& Prilleltensky, O. (2016). Demographic group differences in domain-specific well-being. Journal of Community Psychology, 44(4), 499-515. https://doi.org/10.1002/jcop.21784

Ryan, R. M., \& Deci, E. L. (2001). On happiness and human potentials: A review of research on hedonic and eudaimonic well-being. Annual Review of Psychology, 52(1), 141-166. https://doi.org/10.1146/annurev.psych.52.1.141

Ryan, R. M., Huta, V., \& Deci, E. L. (2008). Living well: A self-determination theory perspective on eudaimonia. Journal of Happiness Studies, 9, 139-170. https://doi.org/10.1007/s10902-006-9023-4

Ryff, C. D. (1989). Happiness is everything, or is it? Explorations on the meaning of psychological wellbeing. Journal of Personality and Social Psychology, 57(6), 1069-1081. https://doi.org/10.1037//00223514.57.6.1069

Ryff, C. D. (1995). Psychological well-being in adult life. Current directions in Psychological Science, 4(4), 99104. https://doi.org/10.1111/1467-8721.ep10772395

Schaie, K. W. (1993). Ageist language in psychological research. American Psychologist, 48(1), 49-51. https://doi.org/10.1037//0003-066x.48.1.49

Scheier, M. F., Wrosch, C., Baum, A., Cohen, S., Martire, L. M., Matthews, K. A., ... Zdaniuk, B. (2006). The Life Engagement Test: Assessing purpose in life. Journal of Behavioral Medicine, 29(3), 291-298. https://doi.org/10.1007/s10865-005-9044-1

Schwartz, H. A., Eichstaedt, J. C., Kern, M. L., Dziurzynski, L., Ramones, S. M., Agrawal, M., ... \& Ungar, L. H. (2013). Personality, gender, and age in the language of social media: The open-vocabulary approach. PloS one, 8(9), e73791. https://doi.org/10.1371/journal.pone.0073791 
Schwarz, N. \& Strack, F. (2016). Reports of subjective well-being: Judgemental processes and their methodological implications. In D. Kahneman; E. Diener; \& N. Schwarz (Eds.), Well-Being: Foundations of Hedonic Psychology (pp. 434-450). [Adobe PDF].

Seligman, M. E. (2011). Flourish: A visionary new understanding of happiness and well-being. New York, NY: Free Press.

Seligman, M. E. (2018). PERMA and the building blocks of well-being. The Journal of Positive Psychology, 13, 333-335. https://doi.org/10.1080/17439760.2018.1437466

Seligman, M. E. P., \& Adler, A. (2018). Positive education. Global happiness policy report, 52-73.

Seligman, M. E. P., \& Adler, A. (2019). Positive education. Global happiness and wellbeing policy report, 5384.

Sheldon, K. M., \& King, L. (2001). Why positive psychology is necessary. American Psychologist, 56(3), 216217. https://doi.org/10.1037//0003-066x.56.3.216

Smith, J., Borchelt, M., Maier, H., \& Jopp, D. (2002). Health and well-being in the young old and oldest old. Journal of Social Issues, 58(4), 715-732. https://doi.org/10.1111/1540-4560.00286

Spinella, M., \& Lester, D. (2006). Can money buy happiness? Psychological Reports, 99(7), 992. https://doi.org/10.2466/pr0.99.7.992-992

Steel, M. (2016a). Personal well-being frequently asked questions. Retrieved from Office for National Statistics website:

https://www.ons.gov.uk/peoplepopulationandcommunity/wellbeing/methodologies/personalwellbei ngfrequentlyaskedquestions

Steel, M. (2016b). Personal well-being user guidance. Retrieved from Office for National Statistics website: https://www.ons.gov.uk/peoplepopulationandcommunity/wellbeing/methodologies/personalwellbei ngsurveyuserguide

Steptoe, A., Deaton, A., \& Stone, A. A. (2015). Psychological wellbeing, health and ageing. The Lancet, 385(9968), 640-648. https://doi.org/10.1016/S0140-6736(13)61489-0

Stevenson, B., \& Wolfers, J. (2013). Subjective well-being and income: Is there any evidence of satiation? American Economic Review: Papers E Proceedings, 103(3), 598-604. https://doi.org/10.1257/aer.103.3.598

Stiglitz, J. E., Sen, A., \& Fitoussi, J. P. (2009). Report by the commission on the measurement of economic performance and social progress. Retrieved from Commission on the Measurement of Economic Performance and Social Progress website: http://ec.europa.eu/eurostat/documents/118025/118123/Fitoussi+Commission+report

Stratton, A. (2010, November 14). David Cameron aims to make happiness the new GDP. The Guardian. Retrieved from http://www.guardian.co.UK/politics/2010/nov/14/david- cameron-wellbeing-inquiry

Thomson, W. (1889). Popular lectures and addresses: Volume 1. Retrieved from https://ia902702.us.archive.org/25/items/popularlecturesa01kelvuoft/popularlecturesa01kelvuoft.pdf

Tooby, J., \& Cosmides, L. (2008). The evolutionary psychology of the emotions and their relationship to internal regulatory variables. In M. Lewis; J. M. Haviland-Jones; \& L. F. Barret. (Eds.), Handbook of Emotions (pp. 114-156). New York, NY: Guilford Press [Adobe PDF]

Tsai, J. L., Knutson, B., \& Fung, H. H. (2006). Cultural variation in affect valuation. Journal of Personality and Social Psychology, 90(2), 288-307. https://doi.org/10.1037/0022-3514.90.2.288

Tversky, A., \& Kahneman, D. (1985). The framing of decisions and the psychology of choice. Behavioral Decision Making, 211(4481), 453-458. https://doi.org/10.1126/science.7455683

UN, GA. (2015). Transforming our world: the 2030 Agenda for Sustainable Development. Division for Sustainable Development Goals: New York, NY, USA.

VanderWeele, T. J. (2017). On the promotion of human flourishing. PNAS Early Edition, 1-9. https://doi.org/10.1073/pnas.1702996114

Vittersø, J., Søholt, Y., Hetland, A., Thoresen, I. A., \& Røysamb, E. (2009). Was Hercules happy? Some answers from a functional model of human well-being. Social Indicators Research, 95(1), 1-18. https://doi.org/10.1007/s11205-009-9447-4.

Waldron, S. (2010). Measuring subjective wellbeing in the UK. Newport: Office for National Statistics. 
Ware Jr, J. E. (2000). SF-36 health survey update. Spine, 25(24), 3130-3139. https://doi.org/10.1097/00007632-200012150-00008

Wallace, K. A., \& Wheeler, A. J. (2002). Reliability generalization of the Life Satisfaction Index. Educational and Psychological Measurement, 62(4), 674-674. https://doi.org/10.1177/001316402128775085

Waterman, A. S. (1993). Two conceptions of happiness: contrasts of personal expressiveness (eudaimonia) and hedonic enjoyment. Journal of Personality and Social Psychology, 64(4), 678-691. https://doi.org/10.1037//0022-3514.64.4.678.

Waterman, A. S. (2007). On the importance of distinguishing hedonia and eudaimonia when contemplating the hedonic treadmill. American Psychologist, 62(6), 612-613. https://doi.org/10.1037/0003-066x62.6.612

Waterman, A. S., Schwartz, S. J., Zamboanga, B. L., Ravert, R. D., Williams, M. K., Bede Agocha, V., ... Brent Donnellan, M. (2010). The Questionnaire for Eudaimonic Well-Being: Psychometric properties, demographic comparisons, and evidence of validity. The Journal of Positive Psychology, 5(1), 41-61. https://doi.org/10.1080/17439760903435208

Watson, D., Clark, L. A., \& Tellegen, A. (1988). Development and validation of brief measures of positive and negative affect: The PANAS scales. Journal of Personality and Social Psychology, 54(6), 1063-1070. https://doi.org/10.1037//0022-3514.54.6.1063

Webste, A., Bode, G., \& Posselt, H. (2008). Measuring wellbeing: The Australian Bureau of Statistics framework for social statistics (ESA/STAT/AC.161). Retrieved from United Nations Department of Economic and Social Affairs: Statistics Division website: https://unstats.un.org/unsd/demographic/meetings/egm/NewYork_812Sep.2008/EGM\%20Papers/Australia\%20-\%20Framework\%20for\%20social\%20statistics.pdf

Weiss, A., King, J. E., Inoue-Murayama, M., Matsuzawa, T., \& Oswald, A. J. (2012). Evidence for a midlife crisis in great apes consistent with the U-shape in human well-being. Proceedings of the National Academy of Sciences, 109(49), 19949-19952. https://doi.org/10.1073/pnas.1212592109

White, M. P., \& Dolan, P. (2009). Accounting for the richness of daily activities. Psychological Science, 20(8), 1000-1008. https://doi.org/10.1111/j.1467-9280.2009.02392.x

World Health Organization. (2015). World report on ageing and health. World Health Organization. 